\title{
PROSAETOMILICHIA DE MEIJERE: A JUNIOR SUBJECTIVE SYNONYM OF MILICHIA MEIGEN, WITH A PHYLOGENETIC REVIEW OF THE MYRMECOPHILA SPECIES-GROUP (DIPTERA, MILICHIIDAE)
}

\begin{abstract}
Brake, I., 1999. Prosaetomilichia de Meijere: a junior subjective synonym of Milichia Meigen, with a phylogenetic review of the myrmecophila species-group (Diptera, Milichiidae). - Tijdschrift voor Entomologie 142: 31-36, figs.1-8. [ISSN 0040-7496]. Published 22 September 1999. Prosaetomilichia de Meijere, 1909, with the Javanese species P. brevirostris and P. myrmecophila, is here synonymized with Milichia Meigen, 1830, because its type-species, M. myrmecophila (de Meijere) comb. n., falls within a monophyletic group in Milichia. This group, the myrmecophila species-group, is characterized by a specialized hind tibia and a black flap at the subcostal break, and also contains the species M. farquharsoni Collin, 1921, M. formicophila Deeming, 1976, and M. patrizii Hennig, 1952. The myrmecophila species-group is part of a larger group of shortfaced Milichia species. M. brevirostris (de Meijere) comb. n. is not a member of the myrmecophila species-group, but also belongs to the group of short-faced Milichia species.

Irina Brake, AG Evolutionsbiologie, Institut für Zoologie, Freie Universität Berlin, KöniginLuise-Str. 1-3, D-14195 Berlin, Germany. E-mail: iribrake@zedat.fu-berlin.de.

Key words. - Milichiidae; Milichia; Prosaetomilichia; taxonomy; phylogenetic systematics
\end{abstract}

In 1909 de Meijere erected a new genus, Prosaetomilichia, to accomodate two new species from Java, $P$. brevirostris and P. myrmecophila. He established this genus on the basis of the shape of the proboscis and the short face, although the species were otherwise similar to Milichia Meigen, 1830. Since de Meijere did not fix a type-species, Sabrosky (1977) subsequently designated $P$. myrmecophila as the type-species of Prosaetomilichia.

Collin (1921), Hennig (1952), and Deeming (1976, 1979, 1984) described a total of nine new short-faced Milichia species from Africa, some of which have an unusually shaped proboscis compared with other Milichia species. These authors preferred to retain these species in Milichia, because they are undoubtedly closely related to the long-faced species.

A study of the type-specimens of Prosaetomilichia myrmecophila and P. brevirostris revealed that they belong to the group of short-faced Milichia species. The purpose of this paper is to determine the correct systematic position of Prosaetomilichia and, having done that, to synonymize Prosaetomilichia with Milichia. I have concluded that it is best to retain these short- faced species in Milichia, and in this I have followed the view of Collin, Hennig and Deeming. In addition, I designate lectotypes for $M$. myrmecophila and M. brevirostris.

Milichia myrmecophila (de Meijere, 1909) comb. n. (figs. 1-5)

Prosaetomilichia myrmecophila de Meijere, 1909: 171. Lectotype ờ (here designated), Java, 'E. Jacobson / Batavia (= Djakarta) / Aug 1908', ZMAN type DIPT. 0724.4, (ZMAN) [examined]

\section{Diagnosis}

Mostly black species with white microtomentum on tergites three to five of the male abdomen. Lunula very high and shining. Wing with a black flap at subcostal break, hind tibia specialized.

\section{Description}

Male. - Head black, except for orange first flagellomere, orange vibrissal angle, and brown palpi.

Frons brown microtomentose, twice as long as 


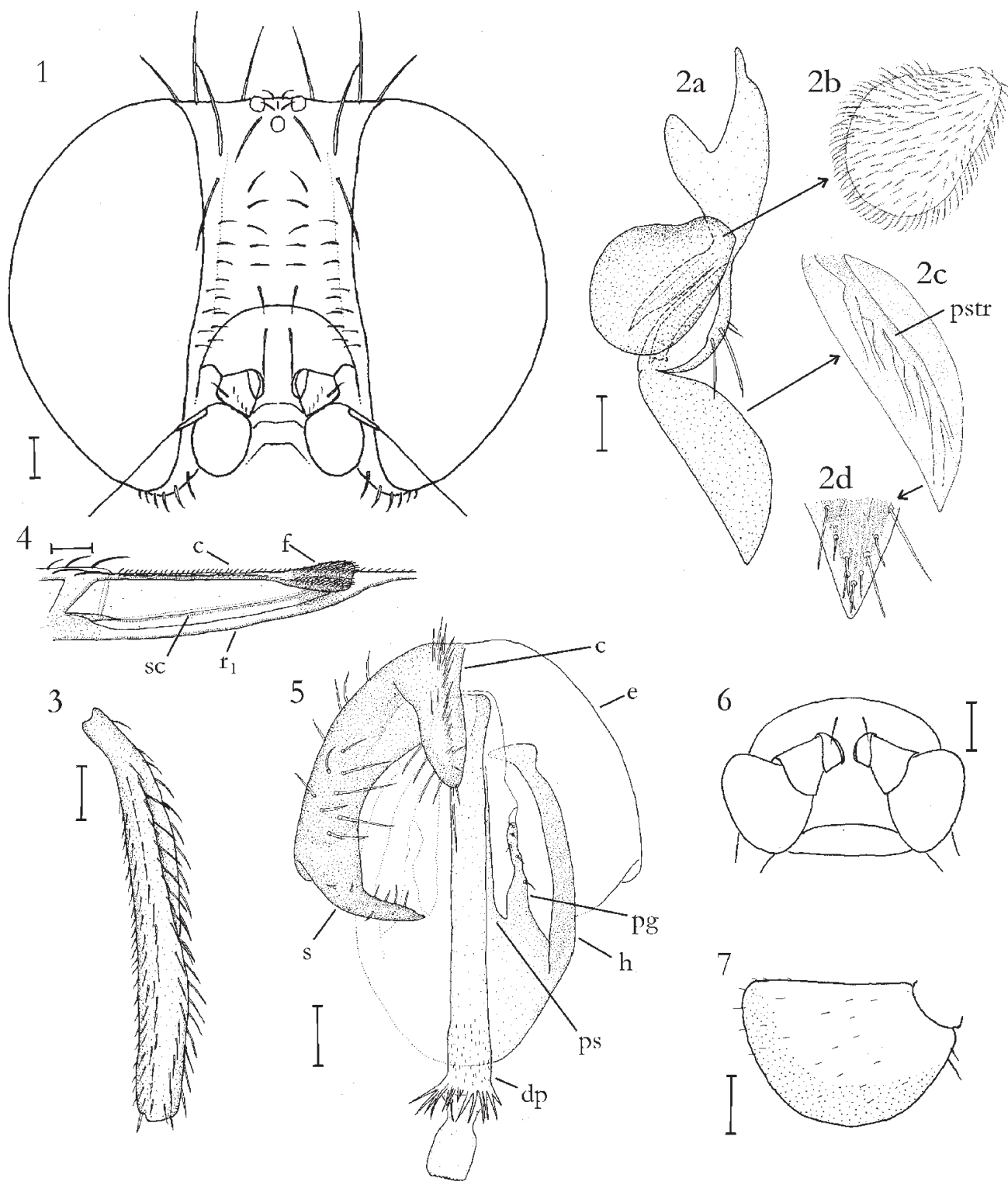

Fig. 1-7. Milichia species. - 1-5. Milichia myrmecophila male. - 1, head (lectotype), frontal view; 2a, proboscis (non-type), lateral view; b, palpus; c, labellum, dorsal side (pstr, pseudotrachea); d, tip of labellum, ventral view; 3, hind tibia (non-type), posterior side; 4, right wing (lectotype), dorsal view of costal cell (c, costa. $\mathrm{f}$, flap. $\mathrm{r}_{1}$, vein $\mathrm{R}_{1}$. sc, subcosta); 5 , male genitalia (non-type), from beneath (c, cerci. dp, distiphallus. e, epandrium. h, hypandrium. pg, pregonite. ps, phallapodemic sclerite. s, surstylus). - 6-7. Milichia brevirostris female. -6, lunule, face and clypeus (lectotype); 7, palpus (paralectotype), lateral view. Scales: $0.1 \mathrm{~mm}$. 
broad with concave sides, narrowest at mid-length where it is $0.28 \times$ width of head, at vertex and base of antennae $0.35 \times$ (fig. 1). Interfrontal hairs in a long row of about seven hairs, the anterior hair longest. Frontal triangle small, not extending further than ocelli. Two orbital setae, upper one reclinate, lower one proclinate. No frontal setae, but two rows of inclinate hairs of equal length. The row on inner side of orbital plate consisting of about eight hairs, the row next to the eye placed anteriorly and consisting of about four hairs. Pro- and lateroclinate ocellar and inner and outer vertical setae present. Postocellar setae slightly converging. Orbital and frontal plates forming one plate, each measuring about one-fifth the width of frons. Orbital setae situated near inner side of plates. Plates shining behind orbital setae, subshining anteriorly. Lunula distinctly shining, with one pair of setae, height about a quarter of the height of frons. Genae narrow, vibrissa strong, followed by a row of bristles which increase in length towards the posterior part of head.

Face short, antennae small, pedicel nearly as long as first flagellomere, which is as long as lunula high. First flagellomere slightly longer than broad. Face and antennae with short pubescence, palpi with hairs of pubescence about twice as long as this. The palpi are round lobes which cover the proboscis at rest (fig. 2a, $2 \mathrm{~b})$. Width of palpi about twice, length slightly less than $3 \times$, height of lunula.

Labium $2.5 \times$, labella about $4 \times$, height of lunula. Labella flat, with five shallow pseudotracheae dorsally (fig. 2c) which disappear before they reach margin of labella (fig. 2d). Labella folded together at rest, microtomentose on outside, with several hairs which are as long as interfrontal hairs.

Thorax black. Mesonotum sparsely, scutellum thickly brown microtomentose, pleura grey microtomentose. Basisternum similar to shape ' $G$ ' in Speight (1969), without precoxal bridge. Mesonotum and scutellum strongly convex.

Thorax about $1.3 \times$ as long as broad. Length of thorax: $1.2 \mathrm{~mm}$.

Chaetotaxy: 1 postpronotal, 2 notopleural, 1 presutural, 2 postalar, 1 long and 1 very short dorsocentral, 1 long prescutellar, 1 apical and 1 subapical scutellar, 3 katepisternal and no anepimeral setae. Apical scutellar setae cruciate and standing vertically upright. Setae long and conspicuous.

Legs black except for yellowish distal end of fore tibia and base of fore and mid tarsus. Coxae thickly grey microtomentose, rest of legs thinly grey microtomentose except for ventral and posterior side of hind femur and upper side of mid and hind tibiae, which are polished and glabrous. Surface of brilliantly pol- ished areas on mid and hind tibia flattened, slightly concave, thus forming a sharp anterodorsal ridge on hind tibia (fig. 3). Distal end of fore tibia and basal two tarsomeres with a brush of yellow setulae. Basal three tarsomeres of hind leg with an anteroventral row of very short black setulae next to a narrow brush of yellow-brown setulae.

Fore tibia short $(0.5 \mathrm{~mm})$, only $0.6 \times$ length of hind tibia $(0.8 \mathrm{~mm})$ (mid tibia: $0.7 \mathrm{~mm})$.

Wings and calypters slightly yellowish, wing with a dark spot at distal end of $R_{1}$ and subcosta next to a black flap at costa near subcostal break. The flap has the shape of a narrow triangle, $0.18 \mathrm{~mm}$ long and $0.10 \mathrm{~mm}$ broad distally (fig. 4). It is microtomentose and the long sides of the triangle are covered with black setulae. $\mathrm{R}_{4+5}$ and $\mathrm{M}_{1+2}$ slightly converging at tip. Last section of $\mathrm{M}_{1+2}$ about 1.5 as long as penultimate section. Cell CuP closed.

Halteres black. Length of wing: $2.9 \mathrm{~mm}$.

Abdomen black, second tergite brown microtomentose except for a polished spot laterally. Third to fifth segments white microtomentose except for distal margin of fifth segment. Tergite 2 with one row of hairs on distal edge and a few scattered hairs. Tergites 3 and 4 with one row of hairs distally. Tergite 5 with a few scattered hairs and some setae at distal end.

Male genitalia (fig. 5) bent under ventral side of abdomen. Surstylus with a pointed tip, not fused to epandrium. Phallapodemic sclerite fused with base of pregonites and with reduced median part of hypandrium. Distiphallus membranous with a ring of hairs near tip.

\section{Body length: $3.3 \mathrm{~mm}$}

Female. - Differs from male in having the frons parallel-sided, $0.4 \times$ width of head. Abdomen polished except for middle of tergite two, which is brown microtomentose. All tergites with a few scattered hairs. Flap on wing $1.4 \times$ as long as in male.

Material examined. - Lectotype cited above. Paralectotypes: 1 male and 1 female on one pin, 'Java Jacobson', ZMAN type DIPT. 0724.6-7 (ZMAN). In addition there are 3 male and 1 female paralectotypes from Aug. 1908, which I did not examine.

Non-type material: Java: 1 male 'E. Jacobson / Batavia / Dec 1908' (ZMAN).

\section{Remarks}

M. myrmecophila comb. $\mathrm{n}$. is closely related to $M$. farquharsoni Collin, 1921, M. formicophila Deeming, 1976 and M. patrizii Hennig, 1952 (see below). It differs from all three by the presence of prescutellar setae. $M$. farquharsoni and M. patrizii differ from M. myrme- 
cophila and $M$. formicophila by their palpi and labella which are of a very peculiar shape and are setose in an unusual way. $M$. formicophila differs from $M$. myrmecophila in having the wing-base infuscate and tergite two of the male largely white microtomentose, whereas it is brown microtomentose in M. myrmecophila.

Milichia brevirostris (de Meijere, 1909) comb. $\mathbf{n}$. (figs. 6, 7)

Prosaetomilichia brevirostris de Meijere, 1909: 172. Lectotype $q$ (here designated), Java, 'E. Jacobson / Batavia (= Djakarta) / Dec 1908', ZMAN type DIPT. 0717.1 (ZMAN) [examined].

[Lectotype originally pinned together with 2 paralectotypes, 2 Formicidae, and 2 Homoptera, but now double staged on a separate pin.]

\section{Diagnosis}

Black species except for orange-yellow base of first flagellomere and palpi and knees. Mesonotum brown microtomentose except anteriorly. Anterior end of mesonotum and pleura grey microtomentose. Distal end of subcosta darkened.

\section{Description}

Female. - Head black except for orange-yellow base of first flagellomere, arista and palpi. First flagellomere and palpi brown only at distal margin.

Frons, lunula, pedicel and face grey microtomentose. Colour of microtomentum on frons changing from grey to brown near vertex. First flagellomere and palpi with white pubescence, which is twice as long on palpi as on first flagellomere.

Frons parallel-sided, 1.2 as long as broad and 0.3 width of head. Interfrontal hairs weak, in a row of about six hairs and with some scattered hairs laterad of the rows, anterior pair longest.

Frontal triangle small, not extending further than ocelli. Two orbital setae, upper one reclinate, lower one proclinate and an additional small proclinate seta placed between these but slightly closer to eye. No frontal setae, but about four hairs. Pro- and lateroclinate ocellar and inner and outer vertical setae present. Postocellar setae parallel. Orbital and frontal plates only distinguished by thicker microtomentum. Lunula short, height about half length of first flagellomere, with one pair of setae (fig. 6). Head in lateral view similar to $M$. argyratoides Collin, 1921 and $M$. cornesi Deeming, 1976 as regards the slight angle in posterior eye margin (Collin 1921: fig. 1, pl. XVII, Deeming 1976: fig. 1). Genae very narrow, vibrissa strong, followed by a row of setae which become shorter at back of head.

Face short (fig. 6), antennae small, pedicel slightly shorter than first flagellomere. First flagellomere slightly broader than long. Palpi semicircular in shape with rounded edges and a few scattered short setulae (fig. 7). Length of palpi: $0.36 \mathrm{~mm}$, width: $0.23 \mathrm{~mm}$. Proboscis completely covered by palpi at rest. Shape of labella as in $M$. myrmecophila.

Thorax black. Mesonotum and scutellum brown microtomentose, but anterior part of mesonotum and pleura grey microtomentose. Basisternum similar to shape 'G' in Speight (1969).

Chaetotaxy: 1 postpronotal, 2 notopleural, 1 presutural, $1+2$ supraalar, 2 postalar, 1 long and 1 short dorsocentral, 1 long prescutellar, 1 cruciate apical and 1 subapical scutellar, 3 katepisternal and no anepimeral setae. Setae long and conspicuous.

Legs black except for yellow knees; grey microtomentose, but polished and glabrous posteriorly on hind femur. Basal two tarsomeres of hind leg with an anteroventral row of short setulae and a ventral brush of yellow setulae.

Wings and calypters hyaline, veins yellow-brown. Distal end of subcosta and $R_{1}$ and costa proximal to subcostal break darkened. $\mathrm{R}_{4+5}$ and $\mathrm{M}_{1+2}$ parallel. Distal section of $\mathrm{M}_{1+2}$ slightly longer than penultimate section. Cell CuP closed. Halteres black. Length of wing: $2.6 \mathrm{~mm}$.

Abdomen black, tergites brown microtomentose except for tergite 1 and basal half of tergite 2, which become more greyish laterally, and except for hind margins of tergites 2-5, which are grey microtomentose. Shoulders of tergite 2 with a tuft of setae.

Body length: $2.0 \mathrm{~mm}$.

Material examined. - Lectotype cited above. Paralectotypes: 2 females pinned together with 2 Formicidae, and 2 Homoptera; Java, 'E. Jacobson / Batavia (= Djakarta) / Dec 1908', ZMAN type DIPT. 0717.2-3 (ZMAN). 1 female, 'Java Jacobson', ZMAN type DIPT. 0717.4 (ZMAN).

\section{Remarks}

$M$. brevirostris comb. $\mathrm{n}$. belongs to the short-faced species of the genus Milichia, sharing the pale first flagellomere, flattened labella, and yellow knees. It is most closely related to $M$. argyratoides, sharing the hyaline wings with darkened end of subcosta and the grey microtomentum anteriorly on the otherwise brown microtomentose mesonotum, but it differs by the colour of the microtomentum on frons, pleura and abdomen. In $M$. argyratoides these parts are completely brown microtomentose, whereas they are partly grey in $M$. brevirostris. In addition, $M$. argyratoides is about twice as long as $M$. brevirostris and is stouter. 
short-faced species of Milichia

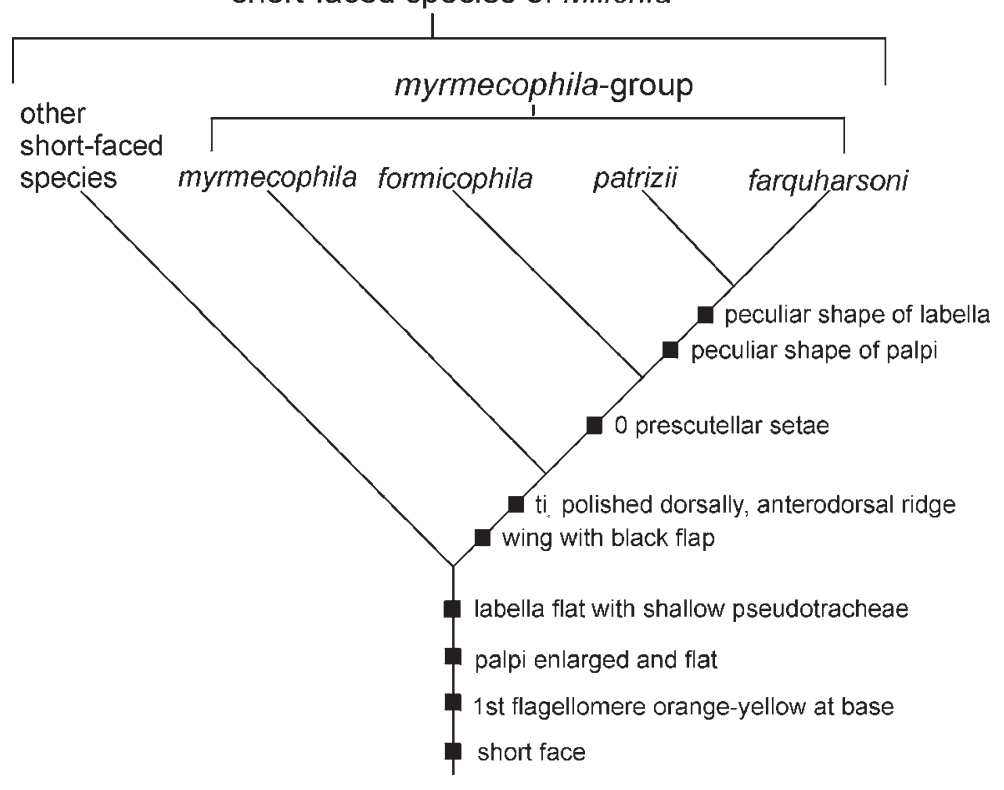

Fig. 8 . Cladogram of the short-faced Milichia species.

\section{Phylogenetic systematics}

The genus Milichia belongs to the subfamily Milichiinae of the Milichiidae. As yet no apomorphies have been identified for this genus. It is characterized by a combination of the following plesiomorphies: anepimeron bare (in contrast to Pholeomyia Bilimek, 1867) and posterior margin of eye entire (in contrast to Milichiella Giglio-Tos, 1895 and Ulia Becker, 1907). The short-faced Milichia species as characterized below belong to the genus Milichia because they share all the generic characters mentioned by Hennig (1938) except for the proboscis, which has elongated labella, and except for the wing, in which $\mathrm{R}_{4+5}$ and $\mathrm{M}_{1+2}$ may converge slightly. The male genitalia are rather similar throughout the genus, but they are only known in a few species.

The short-faced Milichia species constitute a monophyletic group, with several apomorphic characters (fig. 8): 1. short face (plesiomorphic: long face), 2. first flagellomere orange-yellow at base (plesiomorphic: first flagellomere black), 3. palpi enlarged and flat (plesiomorphic: palpi small and spatulate), and 4. labella flattened with shallow pseudotracheae (plesiomorphic: not flattened, with normal pseudotracheae). The myrmecophila species-group belongs to the short-faced group. Apomorphic characters of the myrmecophila species-group are: a black flap on the wing (plesiomorphic: no black flap), and hind tibia polished dorsally, with an anterodorsal ridge (plesiomorphic: hind tibia without a ridge). The group consists of the species $M$. farquharsoni, $M$. formicophila, M. myrmecophila and M. patrizii. M. patrizii and $M$. farquharsoni are sister species with synapomorphies in the palpi and labella, which are both very peculiar in shape and are setose in an unusual way. Together they form the sister-group of $M$. formicophila, with the loss of the prescutellar setae as a synapomorphy.

\section{Biology}

The short-faced Milichia species are probably all myrmecophilous, and so far as is known they have a common behaviour in that there is a feeding interaction between the adult flies and ants, unlike other myrmecophilous Milichiidae such as Pholeomyia and Phyllomyza Fallén, 1810 where no such interaction has been observed. Instead, the larvae of Pholeomyia and Phyllomyza have been found in ants nests, where they probably feed on detritus (Moser \& Neff 1971, Donisthorpe 1927). The adults of Milichia dectes Collin, 1921, M. proectes Collin, 1921, and M. prosaetes Collin, 1921 are known to receive regurgitated food from Crematogaster ants (Collin 1921, Farquharson 1921). M. brevirostris licks the anal secretion of the ant Dolichoderus bituberculatus or feeds directly on honey dew from Homoptera (Membracidae) (de Meijere 1909). M. myrmecophila is thought to lick the anal secretion of Crematogaster difformis: Jacobson (1909) could not really see this, but observed the flies following the ants with their proboscis 
near the abdominal tip of the ants. It is also possible that the flies feed on the abdominal contents of the ants, as described for Rhynchopsilopa flies (Ephydridae) and Crematogaster ants (Freidberg \& Mathis 1985). M. farquharsoni was observed 'haunting the nests of Crematogaster ants', but the exact nature of its behaviour could not be resolved. And, finally, the larvae of $M$. argyratoides were found on the running wound of a Crematogaster ant-tree, covering themselves with excreta. One Crematogaster ant was observed to carry away some of the excreta from the surface of the larva (Farquharson 1921). It would be very interesting to study the biology of this group of flies in greater detail.

\section{ACKNOWLEDGEMENTS}

I am grateful to Dr. H. de Jong (ZMAN, Zoological Museum Amsterdam, Netherlands) for the loan of the Prosaetomilichia specimens, to D. J. Mann (Hope Entomological Collections, Oxford) for the loan of Milichia farquharsoni and M. argyratoides, and to Dr. M. von Tschirnhaus (Universität Bielefeld) for the loan of several Milichia species.

I thank Prof. Dr. W. Sudhaus for critically reviewing the manuscript.

\section{REFERENCES}

Collin, J. E., 1921. Description of a new genus and two new species of Cecidomyidae, and six new species of acalyptrate Muscidae (Ephydridae and Milichiidae). - Transactions of the Entomological Society of London 1921: 504-517.

Deeming, J. C., 1976. Four new short-faced species of the genus Milichia Meigen with a key to the Nigerian members of the group (Diptera: Milichiidae). - Entomologica Scandinavica 7: 35-40.
Deeming, J. C., 1979. A new giant species of Milichia Meigen from Central Africa. - Bulletin de la Société Entomologique de France 84(3-4): 97-99.

Deeming, J. C., 1984. The previously undescribed male of Milichia patrizii Hennig (Dipt. Milichiidae). - Entomologist's monthly Magazine 120: 242.

Donisthorpe, H. S. J. K., 1927. The guests of British ants: their habits and life-histories. - George Routhledge \& Sons. xiii +244 pp.

Farquharson, C. O., 1921. Notes on the life-history of Milichia argyratoides, and the habits of other Milichiidae. - Transactions of the Entomological Society of London 1921: 444-447.

Freidberg, A. \& Mathis, W. N., 1985. On the feeding habits of Rhynchopsilopa [Dip.: Ephydridae]. - Entomophaga 30(1): 13-21.

Hennig, W., 1938. Milichiidae et Carnidae. - In: E. Lindner: Fliegen der palaearktischen Region 60a, II+91 pp.

Hennig, W., 1952. Bemerkenswerte neue Acalyptraten in der Sammlung des Deutschen Entomologischen Institutes (Diptera: Acalyptrata). - Beiträge zur Entomologie 2: 604-618.

Jacobson, E., 1909. Ein Moskito als Gast und diebischer Schmarotzer der Crematogaster difformis Smith und eine andere schmarotzende Fliege. - Tijdschrift voor Entomologie 52: 158-164.

Meijere, J. C. H. de, 1909. Drei myrmecophile Dipteren aus Java. - Tijdschrift voor Entomologie 52: 165-174, pl. 10.

Moser, J. C. \& Neff, S. E., 1971. Pholeomyia comans (Diptera: Milichiidae) an associate of Atta texana: larval anatomy and notes on biology. - Zeitschrift für angewandte Entomologie 69: 343-348.

Sabrosky, C. W., 1977. Milichiidae. - In: Delfinado, M. D. \& Hardy, D. E.: A Catalogue of the Diptera of the Oriental Region 3: 270-274.

Speight, M. C. D., 1969. The prothoracic morphology of acalyptrates and its use in systematics. - Transactions of the Royal Entomological Society of London 121: 325-421.

Received: 25 March 1999

Accepted: 19 May 1999 